\title{
Hygrothermal performance of paper plaster: influence of different types of paper and production methods on moisture buffering
}

\author{
Mihkel Soolepp ${ }^{1}$, Aime Ruus ${ }^{1, *}$, Nele Nutt $^{1,2}$, Jane Raamets $^{1}$ and Ardo Kubjas ${ }^{1}$ \\ ${ }^{1}$ Tallinn University of Technology, School of Engineering, Tartu College, 51008, Puiestee 78, Tartu, Estonia \\ ${ }^{2}$ Tallinn University of Technology, School of Engineering, Department of Civil Engineering and Architecture, Academy of Architecture \\ and Urban Studies, 10119 Tõnismägi 14, Tallinn, Estonia
}

\begin{abstract}
Paper as a material needs a lot of input energy. Many measures have been suggested to recycle paper, but still a huge amount of it ends in landfills. Hereby, one possibility for recycling paper - making paper plaster and putting it into service in indoor environment - is introduced. The study focuses on the moisture buffering properties of paper plaster. Two questions are under consideration in this article. Firstly, how paper type and production method influence the properties (dry density, drying shrinkage) of paper plaster, and secondly, what the material moisture buffering properties of paper plaster are. The plasters for testing were made from four types of paper (printer paper, glossy paper, newsprint and book paper). The production methods used were rumpling, grinding with a shredder or special crusher (prepared for the study) and soaking the paper after that. The dry density of groups varied from approx. $240 \mathrm{~kg} / \mathrm{m}^{3}$ to $400 \mathrm{~kg} / \mathrm{m}^{3}$. The shrinkage properties were from $3 \%$ to $10 \%$ in diameter. To evaluate the moisture buffering ability of paper plaster, the methodology introduced in the Nordtest protocol was used. Paper plaster is an outstanding water vapour buffering material $\left[\mathrm{MBV}=2.23-3.91 \mathrm{~g} /\left(\mathrm{m}^{2} . \% \mathrm{RH}\right)\right]$ belonging to the moisture buffering class "excellent" defined by Rode [15]. From the production methods rumpling gave the best value while printer paper showed the best values from the chosen materials. The tests with glossy paper resulted in modest values. To conclude, all the paper materials and preparation methods introduced in this study can be used to make paper plaster
\end{abstract}

\section{Introduction}

Paper production is a huge branch of industry, and paper recycling and reuse is an area of industry as well. Paper could be recycled several times as paper or carton [1]. A remarkable amount of paper is just burned for heat production [2].

In building material industry paper is used in many ways for example in cellulose insulation [3] and gypsum boards [2]. One way of recycling paper, which is not very commonly used, is making paper plaster [4-6]. Plaster made from paper can be used as an indoor finishing material and here a question arises why paper should be considered from that point of view.

Today we have to build energy efficient houses [7]. Optimal relative humidity and safe hygrothermal conditions on the surface and in the boarders are concerns in all types of buildings [8]. Ensuring good indoor climate may include additional costs and a material with good buffering ability helps to balance moisture fluctuations [9-11].

Paper is a hygroscopic material which has an influence on indoor relative humidity [12]. Measurable parameters like water vapour sorption, water vapour permeability, and moisture buffering value (MBV)
$[13,14]$, and calculable parameters like moisture effusivity $b_{m}$ [15] and hygroscopic inertia $I_{h, d}[16]$ of the room are the parameters which help to evaluate paper plaster.

$M B V_{\text {practical }}$ describes the changes in moisture content in (MC) real situations in rooms with human occupants. The cycle $8 / 16 \mathrm{~h}$ between relative humidity range $\mathrm{RH}=33-75 \%$ has been described by Rode and others $[13,15]$ in the Nordtest protocol. Also, penetration depth and therefore effective thickness [17] of the material are important aspects.

Paper plaster could be prepared in different ways. Everybody can collect waste paper while rumpling and soaking processes are quite easily performed in domestic conditions. Also, production could be mechanized or even industrial if people want to use paper plaster because of its properties and buying a pre-prepared material not getting involved in making the plaster themselves could be an option.

*Corresponding author: aime.ruus@taltech.ee 


\section{Materials and methods}

\subsection{Paper type and plaster production methods}

In the study different types of papers were used: printer paper, glossy paper, newsprint and book paper. Three production methods were tested - rumpling, grinding with a special crusher (Fig.1, 2a) (prepared for the study) or shredder (Fig. 2b) and finally soaking.

A simple recipe was used for plaster: pre-processed paper with a glue solution (ca $500 \mathrm{~g}$ paper +11 water + 20-25 g starch) added.

The specimens moulded in a cylinder (a $110 \mathrm{~mm}$ plastic pipe with the inside diameter of $103 \mathrm{~mm}$ and 25 $\mathrm{mm}$ high) were grouped as follows and left to dry (Fig.3): rumpled printer paper - group 1 (PPR); rumpled book paper - 2 (BPR); shredded printer paper - 3 (PPS); shredded book paper (Fig. 2b) - 4 (BPS); rumpled glossy paper - 5 (GPR); printer paper grinded with a crusher (Fig. 1, 2a ) - 6 (PPC); glossy paper grinded with a crusher -7 (GPC); book paper grinded with a crusher -8 (BPC); newsprint grinded with a crusher - 9 (NPC); shredded glossy paper -10 (GPS).

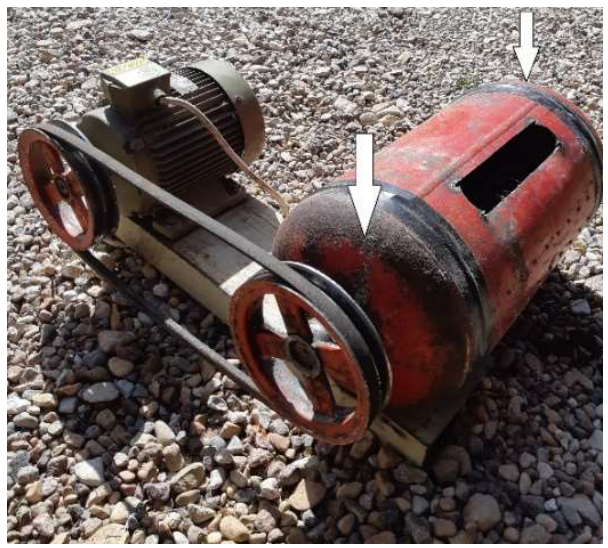

Fig. 1. The paper crusher - made from reused materials.

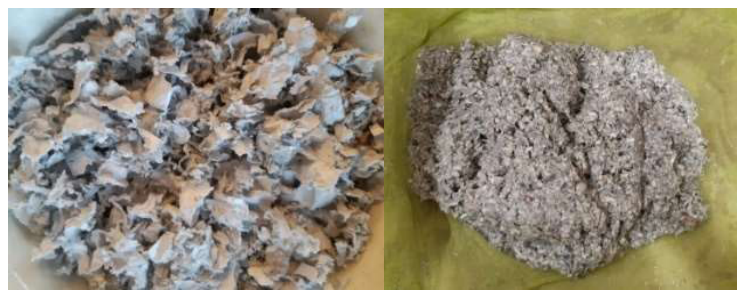

a)

b)

Fig. 2. Grinded paper: a) with a crusher (fresh); b) with a shredder (after soaking)

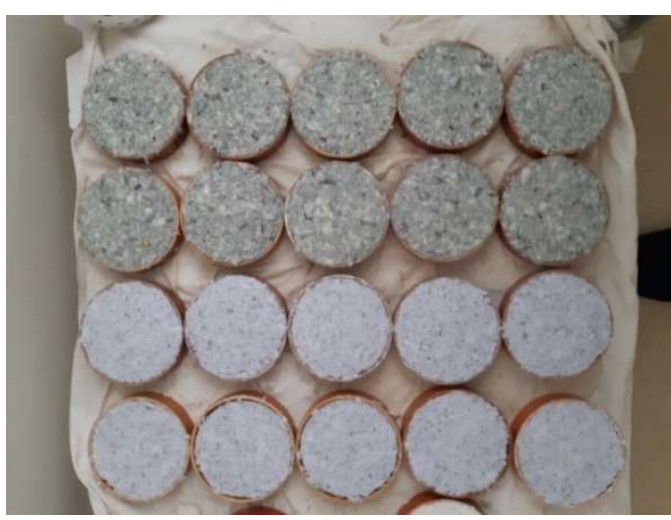

Fig. 3. Specimens during drying process.

\subsection{Sorption test}

Hygroscopic sorption properties were determined by following the principle of the standards EVS-EN ISO 12570:2000 [18] and EVS-EN ISO 12571:2013 [19]. Four different RH levels were tested: $30 \%, 50 \%, 75 \%$ and $95 \%$, at temp $(23 \pm 0.5){ }^{\circ} \mathrm{C}$ and according to standard ranges $(\mathrm{RH}=30-95 \%)$. A plastic film and silicon hermetic were used for tightening. Only one side was exposed to environment to present the situation in real plaster and only one-dimensional moisture transport was enabled. Weighing was carried out with a 24-hour interval until the stabilization of weight (weight gain or release $<0.1 \%$ ). At each $\mathrm{RH}$ level during the first six hours the weighing was carried out more frequently (with a $2 \mathrm{~h}$ interval).

\subsection{Moisture buffering with the Nordtest methodology}

Moisture buffering properties were determined by following the principle of the Nordtest method [13]. The same specimens were used again. Initially, the specimens were acclimatised at $\mathrm{RH}=50 \%$ and $23{ }^{\circ} \mathrm{C}$. After that relative humidity was raised to $\mathrm{RH}=75 \%$ for $8 \mathrm{~h}$ and during that the specimens were weighed with a 2-hour interval. Then relative humidity was lowered to $\mathrm{RH}=33 \%$ for $16 \mathrm{~h}$, and the specimens were weighed once in 2 hours after lowering the $\mathrm{RH}$ once. No weighing took place during the last 14 hours. The total study cycle was 24 hours $-8 / 16 \mathrm{~h}$.

The formula for $\mathrm{MBV}_{8 \mathrm{~h}}\left[\mathrm{~g} /\left(\mathrm{m}^{2} . \% \mathrm{RH}\right)\right]$ calculations (Formula 1)[9] could be used :

$$
M V B_{8 h}=\frac{m_{\max }-m_{\min }}{A \cdot\left(\varphi_{\text {high }}-\varphi_{\text {low }}\right)}
$$

where $\mathrm{m}_{\min / \max }$ is moisture mass ( $\min$ and $\max$ ) in the finished sample ( $\mathrm{g}$ or $\mathrm{kg}$ ), $\mathrm{A}$ - exposed area $\mathrm{m}^{2} ; \varphi$ high/low - high/low RH (\%) levels. Using the moisture buffering values $\left[\mathrm{g} /\left(\mathrm{m}^{2} . \% \mathrm{RH}\right) 8 / 16 \mathrm{~h}\right]$ materials can be classified as follows: negligible (0-0.2), limited (0.2-0.5), moderate (0.5-1.0) good (1.0-2.0), excellent (2.0-). 


\subsection{Water vapour permeability}

Water vapour transmission properties were estimated by using wet cup method condition $\mathrm{C}$ (air temperature $23^{\circ} \mathrm{C}$, RH 50/93\%) (EVS-EN ISO 12572:2016) [20]. Weighing interval was $24 \mathrm{~h}$ which was performed until stabilisation.

\subsection{Hygroscopic inertia and moisture effusivity}

Using the parameters gathered in the previous tests some calculations were made.

Daily hygroscopic inertia index, $I_{\mathrm{h}, \mathrm{d}}, \mathrm{g} /\left(\mathrm{m}^{3} \% \mathrm{RH}\right)$ was defined by Ramos and others $[12,16]$ as a function of MBV taking ventilation and time (Formula 2) into account

$$
I_{h, d}=\frac{\sum_{i}^{n} M B V_{i} \cdot S_{i}+\sum_{j}^{m} M B V_{o b j}}{a c h \cdot V \cdot t_{g}}
$$

where $M B V_{\text {obj }}, M B V_{i}$ - the moisture buffering value of objects and elements. $S_{i}$ - the surface of an element $i$ $\mathrm{m}^{2}$ ach- air exchange rate $\mathrm{h}^{-1}, \mathrm{~V}$ - room volume $\mathrm{m}^{3}, \mathrm{t}_{\mathrm{g}}-$ vapour production period, $h$.

When we take an example room (only its wall area) with measurements $3 \times 4 \times 2.6 \mathrm{~m}$ (windows and doors approx. $\left.4 \mathrm{~m}^{2}\right)$, where the ventilation rate is $0.42 \mathrm{l} /\left(\mathrm{sm}^{2}\right)$ [21] according to the energy efficiency requirements, it is possible to calculate (by using Formula 2) the daily hygroscopic inertia index of the room. To describe the effect the hygroscopic inertia an alternative calculation was made with ventilation rate $0.15 \mathrm{l} /\left(\mathrm{sm}^{2}\right)$.

Also, calculations were made with the case when only one wall was covered with paper plaster

Moisture effusivity $\mathbf{b}_{m}\left[\mathrm{~kg} /\left(\mathrm{m}^{2} \quad \mathrm{~Pa} \mathrm{~s}^{1 / 2}\right)\right]$ was determined with Formula 3 introduced by Rode and others [15] and was based on material properties measured under steady state and equilibrium conditions.

$$
b_{m}=\sqrt{\frac{\delta_{p} \cdot \rho_{0} \cdot \frac{\partial u}{\partial \varphi}}{p_{s}}},
$$

where $\delta_{p}[\mathrm{~kg} /(\mathrm{m} \cdot \mathrm{s} \cdot \mathrm{Pa})]$ is water vapour permeability, $\rho_{0}\left[\mathrm{~kg} / \mathrm{m}^{3}\right]$ dry density of the material, $u[\mathrm{~kg} / \mathrm{kg}]$ moisture content, $\phi[-]$ relative humidity, and $p_{s}[\mathrm{~Pa}]$ saturation vapour pressure. Apart from $p_{s}$, which is given by the test conditions, the other parameters in the definition of $\mathrm{bm}$ are all standard material properties estimated in the study.

\section{Results}

\subsection{Density and shrinkage of specimens}

The data of dried specimen groups are presented in Table 1. The highest shrinkage was observed in group 5 - rumpled glossy paper (shrinkage 9.7\%) and group 10 - shredded glossy paper. Group 8 - crushed book paper kept its form the best (shrinkage 2.7\%). Glossy paper had the highest dry density (rumpled - 5 and shredded - 10) -400.0 and $377.1 \mathrm{~kg} / \mathrm{m}^{3}$ accordingly. The density of newsprint was $240.0 \mathrm{~kg} / \mathrm{m}^{3}$. In general, it can be concluded that glossy paper had the highest density while book and printer paper were quite similar. If production technology was under consideration, it seemed that rumpling gave the highest density, all in all, the density values indicated that paper plaster is a lightweight material compared with gypsum [22] or clay plaster [23, 24].

Table 1. The data of dried specimens: diameter (d, $\mathrm{mm})$, thickness $(\mathrm{h}, \mathrm{mm})$, dry density $\left(0, \mathrm{~kg} / \mathrm{m}^{3}\right)$

\begin{tabular}{|c|c|c|c|}
\hline Group & $\mathbf{d}, \mathbf{m m}$ & $\mathbf{h}, \mathbf{m m}$ & $\begin{array}{c}\mathbf{\rho} \mathbf{}, \\
\mathbf{k g} / \mathbf{m}^{\mathbf{3}}\end{array}$ \\
\hline $1-\mathrm{PPR}$ & 95.19 & 21.93 & 345.5 \\
\hline $2-\mathrm{BPR}$ & 94.71 & 24.02 & 336.6 \\
\hline $3-\mathrm{PPS}$ & 98.15 & 23.65 & 291.2 \\
\hline $4-\mathrm{BPS}$ & 98.01 & 23.33 & 294.0 \\
\hline $5-\mathrm{GPR}$ & $\mathbf{9 2 . 9 9}$ & $\mathbf{1 9 . 6 7}$ & $\mathbf{4 0 0 . 0}$ \\
\hline $6-\mathrm{PPC}$ & 96.69 & 21.96 & 312.7 \\
\hline $7-\mathrm{GPC}$ & 96.63 & 21.12 & 342.6 \\
\hline $8-\mathrm{BPC}$ & $\mathbf{1 0 0 . 2 1}$ & $\mathbf{2 3 . 8 1}$ & 262.8 \\
\hline 9- NPC & 97.70 & 22.27 & $\mathbf{2 4 0 . 0}$ \\
\hline $10-\mathrm{GPS}$ & $\mathbf{9 3 . 7 9}$ & $\mathbf{2 0 . 6 5}$ & $\mathbf{3 7 7 . 1}$ \\
\hline
\end{tabular}

\subsection{Sorption properties}

The weight gain was more intensive within the first hours (Fig. 4) and half of water vapour uptake was gained within the first day, while whole stabilisation was recorded after 216 hours (at $\mathrm{RH}=75-95 \%$ ) or 144 hours (RH=95-75\%).

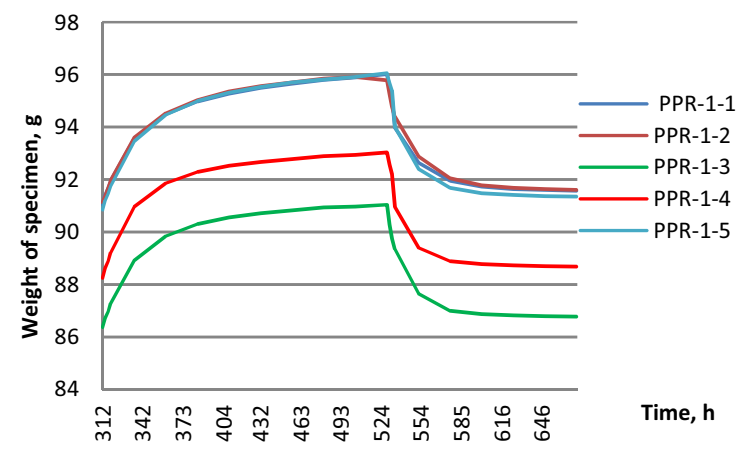

Fig. 4. weight gain of 1 - PPR specimens at $\mathrm{RH}=75-95 \%$ and $\mathrm{RH}=95-75 \%$ )

The sorption test results are presented in Fig. 5, 6 and Table 2 (50 and $95 \%$ of $\mathrm{RH}$ ). Moisture content was determined by comparison to the weight after drying in an ovn at temperature of $40{ }^{\circ} \mathrm{C}$. The highest values of moisture content (MC) at all $\mathrm{RH}$ values were shown by newsprint (only one sample grinded with a crusher) - up 
to $\mathrm{MC}=18 \%$ at $\mathrm{RH}=95 \%$. The second and third (at $\mathrm{RH}=95 \%)$ moisture content values were observed with rumpled printer paper $(1-\mathrm{PPR}, \mathrm{MC}=16 \%)$ and rumpled book paper (2-BPR, MC $=15.9 \%$ ). At $50 \%$ and $75 \%$ of $\mathrm{RH}$ the book paper crushed (8-BPC) had higher moisture content values $\mathrm{MC}=4.4 \%(\mathrm{RH}=50 \%) \uparrow$, $\mathrm{MC}=7.7 \%(\mathrm{RH}=75 \%) \uparrow, \quad \mathrm{MC}=9.1 \%(\mathrm{RH}=75 \%) \downarrow$, $\mathrm{MC}=5.5 \%(\mathrm{RH}=50 \%) \downarrow$.

The lowest MC values at all RH levels were offered by rumpled glossy paper (5-GPR): $\mathrm{MC}=3.2 \%(\mathrm{RH}=50 \%) \uparrow, \quad \mathrm{MC}=5.9 \%(\mathrm{RH}=75 \%) \uparrow$, $\mathrm{MC}=12.9 \%(\mathrm{RH}=95 \%), \quad \mathrm{MC}=7.9 \%(\mathrm{RH}=75 \%) \downarrow$, $\mathrm{MC}=4.1 \%(\mathrm{RH}=50 \%) \downarrow$.

Comparing paper types, printer paper and book paper had higher performance in moisture content. Comparing technologies, it could be seen that on average rumpling gave higher moisture content values.

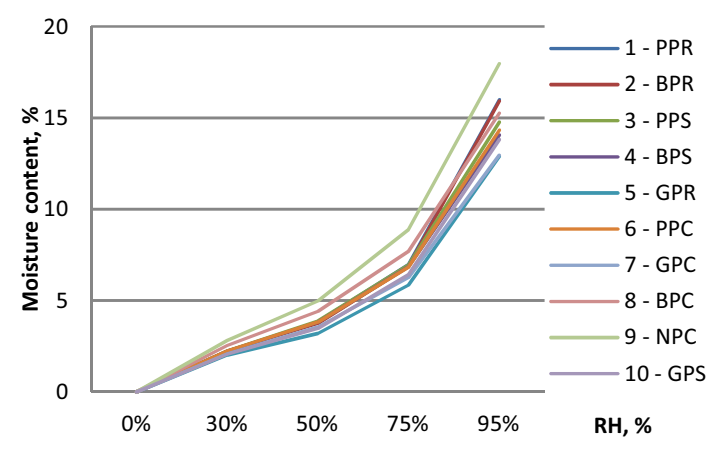

Fig. 5. Adsorption curves

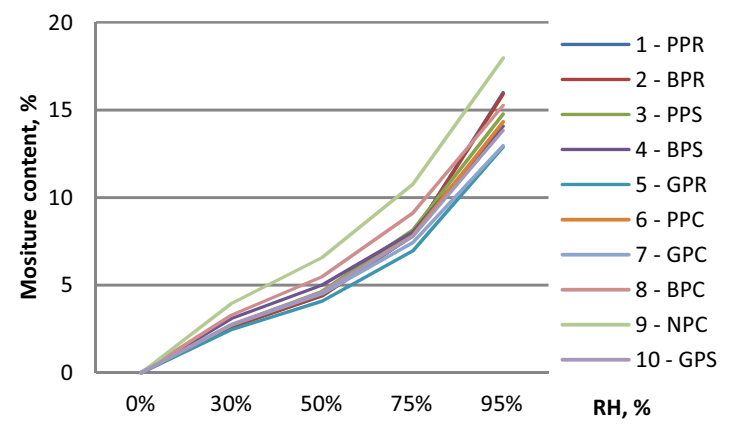

Fig. 6. Desorption curves

\subsection{Moisture buffering}

To describe the moisture buffering fluctuation, moisture content in specimens (g) was measured with regular weighing (Fig. 7). Water vapour uptake and release were higher strictly after changing the RH level (Fig. 8)

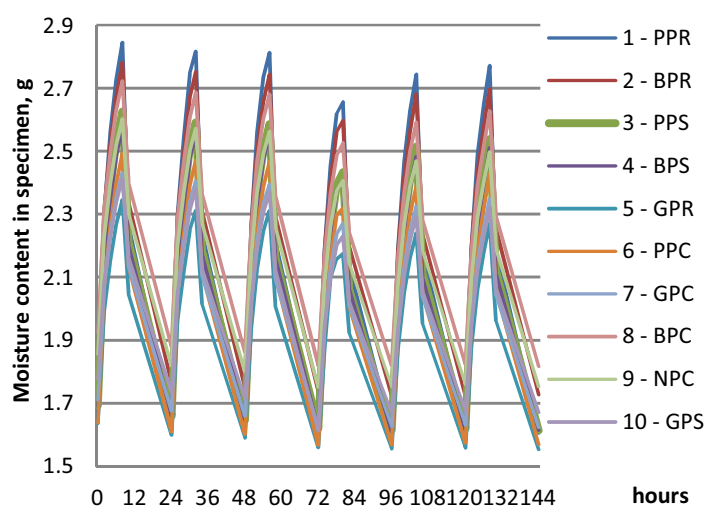

Fig. 7. The fluctuation of moisture content in specimens

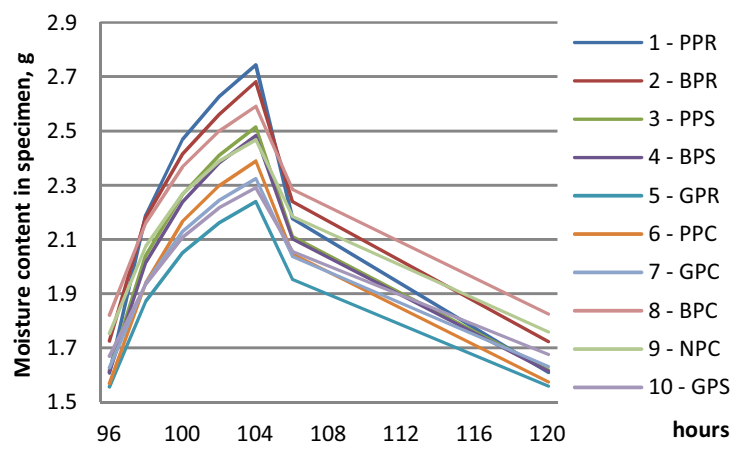

Fig. 8. Moisture uptake and release

Moisture buffering (plaster thickness 2.0-2.4 cm) was calculated (Formula 1) for every cycle (Fig.9, Table 2) It can be seen that one day was different. On March $1^{\text {st }}$ weighing was performed by another person and the difference in data showed how sensitive testing process was if automation was not used. These values (from March $1^{\text {st }}$ ) were excluded from the calculation of average results. Rumpled printer paper (1 - PPR and 2 - BPR) showed higher MBV values [3.91 and 3.31 $\left.\mathrm{g} /\left(\mathrm{m}^{2} . \% \mathrm{RH}\right)\right]$. Shredded and crushed glossy paper [2.20 and $\left.2.33 \mathrm{~g} /\left(\mathrm{m}^{2} . \% \mathrm{RH}\right)\right]$ resulted in modest values.

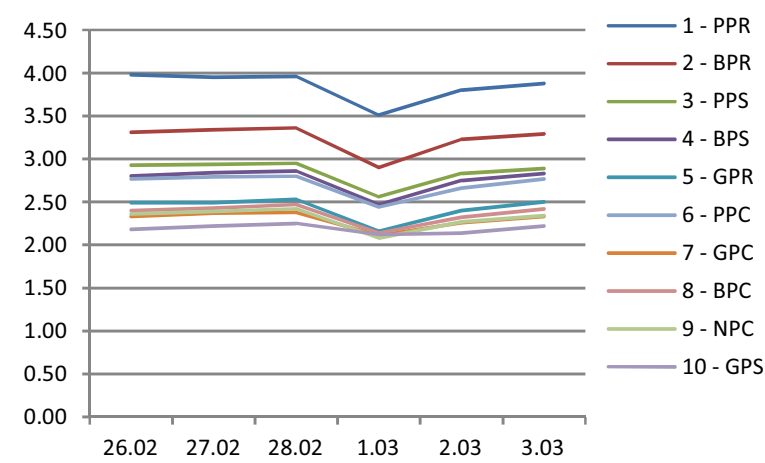

Fig. 9. MBV calculated by using adsorption data 


\subsection{Water vapour permeability}

Testing of water vapour permeability needs more space in climate chamber than sorption and moisture buffering tests because of the size of the testing cups. Therefore, only 8 types of specimens were tested. Newsprint and shredded glossy paper were excluded. Water vapour permeability was estimated with the wet cup method and the results can be seen in Table 2 .

The water vapour resistance factor varied from $\mu=3.0-5.1 \quad\left(\mathrm{~S}_{\mathrm{d}}=0.07-0.11 \mathrm{~m}\right.$, thickness $\left.2.0-2.4 \mathrm{~cm}\right)$. Printer paper rumpled (1 - PPR) and book paper rumpled (2 - BPR) which had the highest MBV and MC as well showed the highest resistance. Other specimens acted quite uniformly $(\mu=3.0-3.8)$.

Table 2. $\mathrm{MC}$ at $\mathrm{RH}=50 \%, \mathrm{RH}=95 \%$, water vapour resistance factor , -, water vapour diffusion-equivalent thickness $\mathrm{S}_{\mathrm{d}}, \mathrm{m}(2-2.4 \mathrm{~cm}$ plaster $), \mathrm{MBV}_{8 / 16 \mathrm{~h}}, \mathrm{~g} /\left(\mathrm{m}^{2 . \%} \mathrm{RH}\right)$

\begin{tabular}{|c|c|c|c|c|}
\hline Group & $\begin{array}{c}\text { MC at } \\
\text { RH50\% } \uparrow\end{array}$ & $\begin{array}{c}\text { MC at } \\
\text { RH95\% }\end{array}$ & $\begin{array}{l}\boldsymbol{\mu} / \mathbf{S}_{\mathbf{d}} \\
-/ \mathbf{m}\end{array}$ & $\begin{array}{c}\text { MBV } 8 / 16 \\
\text { (ads) }\end{array}$ \\
\hline 1 - PPR & 3.8 & 16.0 & 4.6/0.10 & 3.91 \\
\hline 2 - BPR & 3.8 & 15.9 & $5.1 / 0.11$ & 3.31 \\
\hline 3 - PPS & 3.9 & 14.8 & $3.4 / 0.07$ & 2.91 \\
\hline 4 - BPS & 3.8 & 14.1 & $3.2 / 0.07$ & 2.82 \\
\hline 5 - GPR & 3.2 & 12.9 & $3.3 / 0.07$ & 2.48 \\
\hline 6 - PPC & 3.8 & 14.3 & $3.8 / 0.07$ & 2.76 \\
\hline 7 - GPC & 3.6 & 13.0 & $3.0 / 0.08$ & 2.33 \\
\hline 8 - BPC & 4.4 & 15.2 & 3.1/0.07 & 2.41 \\
\hline 9 - NPC & 5.0 & 18.0 & N/A & 2.36 \\
\hline 10 - GPS & 3.5 & 13.8 & N/A & 2.20 \\
\hline
\end{tabular}

\subsection{Hygroscopic inertia and moisture effusivity}

Table 3 presents the calculated parameters: hygroscopic inertia $\mathrm{I}_{\mathrm{h}, \mathrm{d}}$ at three cases and moisture effusivity $\mathrm{b}_{\mathrm{m}}$.

Hygroscopic inertia was calculated (Formula 2) in four example cases. The highest values (1.38-2.45) were obtained when all the walls $\left(32.4 \mathrm{~m}^{2}\right)$ were plastered and the ventilation rate was $0.15 \mathrm{l} /\left(\mathrm{sm}^{2}\right)$ which is minimum for the ventilation rate in dwellings with demand-based ventilation [21]. A remarkable effect could be observed even when only one wall $(4 \times 2.6 \mathrm{~m})$ was plastered and the ventilation rate was minimum [0.48-0.79 g/(moRH)] - class IV according to Ramos and Freitas [16].

If materials and technologies are compared, the lining was the same as for MBV, because of the nature of the Formula.

The moisture effusivity $b_{\mathrm{m}}$ was $5.56^{*} 10^{-7}-6.88 * 10^{-7}$ $\mathrm{kg} /\left(\mathrm{m}^{2} \mathrm{~Pa} \mathrm{~s}^{1 / 2}\right)$. In general, the values for moisture buffering of paper plaster were comparable with sprayed hemp concrete [25] and cellulose insulation being clearly higher than concrete (2-3 times), wood (2-3 times) expanded polystyrene or mineral wool (at least 10 times) found by Rode and others [26].

Table 3. Hygroscopic inertia $\mathrm{H}_{\mathrm{h}, \mathrm{d}}\left[\mathrm{g} /\left(\mathrm{m}^{3} \% \mathrm{RH}\right)\right]$ and moisture effusivity $b_{m}\left[\mathrm{~kg} /\left(\mathrm{m}^{2} \mathrm{~Pa} \mathrm{~s}^{1 / 2}\right)\right]$.

\begin{tabular}{|c|c|c|c|c|c|}
\hline \multirow[t]{2}{*}{ Group } & \multicolumn{2}{|c|}{$\begin{array}{c}\mathbf{I}_{\mathrm{h}, \mathrm{d}} \\
\text { walls are } \\
\text { plastered }\end{array}$} & \multicolumn{2}{|c|}{$\begin{array}{c}\mathbf{I}_{\mathrm{h}, \mathrm{d}} \\
\text { one wall is } \\
\text { plastered } \\
(4 * 2.6 \mathrm{~m}) \\
\end{array}$} & \multirow[t]{2}{*}{$\mathbf{b}_{\mathbf{m}}$} \\
\hline & $\begin{array}{c}0.42 \\
1 /\left(\mathrm{sm}^{2}\right)\end{array}$ & $\begin{array}{c}0.15 \\
1 /\left(\mathrm{sm}^{2}\right)\end{array}$ & $\begin{array}{c}0.42 \\
1 /\left(\mathrm{sm}^{2}\right)\end{array}$ & $\begin{array}{c}0.15 \\
1 /\left(\mathrm{sm}^{2}\right)\end{array}$ & \\
\hline 1-PPR & 0.87 & 2.45 & 0.28 & 0.79 & 5.99 \\
\hline 2-BPR & 0.74 & 2.07 & 0.24 & 0.66 & 5.56 \\
\hline 3-PPS & 0.65 & 1.82 & 0.21 & 0.58 & 6.33 \\
\hline 4-BPS & 0.63 & 1.76 & 0.20 & 0.57 & 6.55 \\
\hline 5-GPR & 0.55 & 1.55 & 0.18 & 0.50 & 6.94 \\
\hline 6-PPC & 0.62 & 1.72 & 0.20 & 0.55 & 6.15 \\
\hline 7-GPC & 0.52 & 1.46 & 0.17 & 0.47 & 6.88 \\
\hline 8-BPC & 0.54 & 1.51 & 0.17 & 0.48 & 6.74 \\
\hline 9-NPC & 0.53 & 1.47 & 0.17 & 0.47 & N/A \\
\hline 10GPS & 0.49 & 1.38 & 0.16 & 0.44 & N/A \\
\hline
\end{tabular}

\section{Discussion and conclusions}

There are several ways how paper plaster can be produced, and everybody can choose a suitable solution. There is a slight difference in hygrothermal properties when different production methods or paper types are used - water vapour permeability $(\mu=3.0-5.1)$, sorption ( $\mathrm{MC}=12.9-18 \%$ at $\mathrm{RH}=95 \%)$, moisture buffering properties $\left[\mathrm{MBV}_{8 / 16 \mathrm{~h}}=2.2-3.9 \mathrm{~g} /\left(\mathrm{m}^{2} . \% \mathrm{RH}\right)\right]$ but in general the material has excellent hygrothermal properties and everybody can use the way which suits them best to make paper plaster. Also, there is no need to plaster the whole room because every square meter covered with paper plaster has a significant influence on the hygroscopic inertia of the room.

The question of the study was to find out which production method gives the "best" material. In general, it is possible to produce plaster at home using waste paper or buy pre-prepared material. There are a few ideas how to produce paper plaster:

1) Gather paper waste from the household and get a "homemade product" by rumpling and soaking the paper.

2) Another way is to collect paper and use a shredder or crusher (which could be borrowed).

3) The easiest way is to buy grinded paper and after soaking it for a while receive a usable product.

A rough calculation shows that for covering $1 \mathrm{~m}^{2}$ of wall with a 2-cm-thick plaster, 16-17 newspapers or one pack of printer paper is needed.

Compared with clay or other mineral plasters paper plaster is remarkably lighter $\left(240-400 \mathrm{~kg} / \mathrm{m}^{3}\right.$ vs $\left.1360-1900 \mathrm{~kg} / \mathrm{m}^{3}\right)[23,23]$. 
Air quality aspects were not studied in the current research but knowledge about any emissions is important and needs further investigation. Also the physical properties could change when components imparting fire resistance are added.

This research did not receive any specific grant from funding agencies in the public, commercial, or non-profit sectors and was supported by Tartu College of Tallinn University of Technology.

\section{References}

1. Scrap paper. https://www.rappin.ee/eng/services-1 (Accessed 20 January 2020)

2. Papp ja Paber. Keskkonnaministeerium. https://www.envir.ee/sites/default/files/huvitavaid fakte $p$ aber_ja_papp_0.pdf (Accessed 23 May 2019)

3. Mis on tselluvill. https://villavennad.ee/mis-on-tselluvill/ (Accessed 20 January 2020)

4. R. Pere, (2008). Looduslikud ehitusmaterjalid. Seinad, põrand, katused ja siseviimistlus. Tallinn: AS Ajakirjade Kirjastus.

5. K. Priilinn (2007). Paberkrohv aitab heli summutada. Äripäev. https://www.aripaev.ee/uudised/2007/08/14/paberkrohvaitab-heli-summutada (Accessed 23 May 2019).

6. J. Metslang 2012. Vana maamaja käsiraamat. Tallinn: Tammeraamat.

7. Ehitusseadustik. (Accessed 19 January 2020) https://www.riigiteataja.ee/akt/121122019005

8. EVS 932:2017 Hoone ehitusprojekt https://www.evs.ee/tooted/evs-932-2017 (Accessed 19 January 2020)

9. H. Janssen, A. Roels. Qualitative and quantitative assessment of interior moisture buffering by enclosures. Energy Build, 41(4), 2009. 382-394. https://doi.org/10.1016/j.enbuild.2008.11.007

10. M. Zhang, Z. Chen. Moisture Buffer Effect and its Impact on Indoor Environment Procedia Engineering, 205, 2017. 1123-1129. https://doi.org/10.1016/j.proeng.2017.10.417

11. M. Zhang, M. Qin, C. Rode, Z. Chen. Moisture buffering phenomenon and its impact on building energy consumption. Applied Thermal Engineering 124, (9) 2017 ,

337-345 http://dx.doi.org/10.1016/j.applthermaleng.2017. $\underline{05.173 .}$.

12. N. M. M. Ramos, V.P. Freitas. Laboratory testing for daily hygroscopic inertia assessment. In: Proceedings of the 8th symposium on building physics in the Nordic countries. 2008. Copenhagen: Denmark 809-816.

13. C. Rode. Moisture buffering of building materials. Report BYG·DTU R-126, 2005. http://orbit.dtu.dk/fedora/objects/orbit:75984/datastreams/ file 2415500/content (Accessed 01 May 2019)

14. K. Svennberg. Moisture Buffering in the Indoor Environment. 2006. (Doctoral dissertation). http://www.byfy.lth.se/fileadmin/byfy/files/TVBH1000pdf/TVBH-1016KSVweb.pdf (accessed 01 May 2019)

15. C. Rode, R. Peuhkuri, B. Time, K. Svennberg, T. Ojanen. Moisture Buffer Value of Building Materials. Journal of ASTM International, vol. 4, no. 5, 2007.
16. H. M. M. Ramos, J. M. P. Q. Delgado, V. P. Freitas. Influence of finishing coatings on hygroscopic moisture buffering in building elements. Constr Build Mater 24, 2010, 2590-2597.

17. D. Maskell, A. Thomson, P. Walker, M. Lemke. Determination of optimal plaster thickness for moisture buffering of indoor air. BuildEnviron. 130, 2018, 143-150 https://doi.org/10.1016/j.buildenv.2017.11.045

18. EVS-EN ISO 12570:2000 Hygrothermal performance of building materials and products -Determination of moisture content by drying at elevated temperature. Retrieved from https://www.evs.ee/tooted/evs-en-iso$\underline{12570-2000}$

19. EVS-EN ISO 12571:2013 Hygrothermal performance of building materials and products - Determination of hygroscopic sorption properties. Retrieved from https://www.evs.ee/tooted/evs-en-iso-12571-2013

20. EVS-EN ISO 12572:2016 Hygrothermal performance of building materials and products - Determination of water vapour transmission properties - Cup method. Retrieved from https://www.evs.ee/tooted/evs-en-iso-12572-2016

21. Riigi teataja. Energiatõhususe miinimumnõuded. https://www.riigiteataja.ee/akt/113122018014 (Accessed 13 June 2019)

22. EVS-EN ISO 10456:2008. Building materials and products. Hygrothermal properties. Tabulated design values and procedures for determining declared and design values. https://www.evs.ee/tooted/evs-en-iso10456-2008 (Accessed 09 January 2020).

23. O. Vares, A. Ruus, J. Raamets, E. Tungel. Determination of hygrothermal performance of clay-sand plaster: influence of covering on sorption and water vapour permeability. Energy Procedia, 132, 2017, 267-272. https://doi.org/10.1016/j.egypro.2017.09.719

24. E. Altmäe, A. Ruus, J. Raamets, E. Tungel. Determination of Clay-Sand Plaster Hygrothermal Performance: Influence of Different Types of Clays on Sorption and Water Vapour Permeability. Springer Proceedings in Energy: The Cold Climate HVAC2018 The 9th International Cold Climate Conference Sustainable new and renovated buildings in cold climates Kiruna - Sweden 12-15, March 2018. Springer, 945-955 https://doi.org/10.1007/978-3-030-00662-4_80

25. F. Collet, S. Pretot. Experimental investigation of moisture buffering capacity of sprayed hemp concrete . Constr Build Mater 36, 2012, 58-65. http://dx.doi.org/10.1016/j.conbuildmat.2012.04.139

26. C. Rode, R. Peuhkuri, K. K. Hansen, B. Time, A. Gustavsen, K. Svennberg, J. Arfvidsson, L.-E. Harderup, T. Ojanen. Moisture buffer value of Materials in Buildings.

https://bwk.kuleuven.be/bwf/projects/annex41/protected/d ata/DTU\%20Apr\%202006\%20Prese\%20A41-T4-Dk-061.pdf (Accessed 09 January 2020). 